\title{
A Woolly Monkey Rediscovered in Peru
}

\section{Russell A. Mittermeier, Hernando de Macedo Ruiz, and Anthony Luscombe}

The Peruvian yellow-tailed woolly monkey, last seen by scientists in 1926 and feared extinct, was rediscovered by the authors in the area of the lower Andes where it was last seen. They were able to bring back a live juvenile that was being kept as a pet, and also four skins and three skulls which they got from a hunter who had shot the animals for meat. The authors urge the need to create a reserve for this rare endemic monkey in Peru and plan further exploratory trips to decide the best area.

The two species of large prehensile-tailed woolly monkeys are found primarily in the Amazon basin. Lagothrix lagothricha is divided into four subspecies, all widely distributed in the rain forests of Brazil, Colombia, Peru, Ecuador and Bolivia, all commonly exhibited in zoos, and all, until recently, frequently sold as pets. L. flavicauda, the Peruvian yellow-tailed woolly monkey, however, is restricted to a small area in Peru and occurs only in finger-like projections of Amazon forest into the Andes. The rarest of New World monkeys, until last year it was known only from five museum specimens, the last collected in 1926. Scientists thought it might already be extinct. Early in 1974 we organised a brief expedition to the area where the last known specimens had been collected, and were able to obtain proof, in the form of four skins, three skulls and the first living specimen ever seen by members of the scientific community, that the monkey still existed. We were also able to get an idea of 
the animal's habitat, its relations with man, and how its continued survival could best be ensured.

\section{History}

L. flavicauda was discovered by the famous German explorer-naturalist Alexander von Humboldt in 1802 and subsequently described, in Humboldt and Bonpland's Recueil d'observations de zoologie et d'anatomie comparée (1812), as Simia flavicauda, 'le Choro de la Province de Jaen' - Choro is the Peruvian name for woolly monkey. Humboldt described the animal as a large, dark brown, long-haired monkey with a ventral tail-callosity and distinguished primarily by a yellow ventral band on the distal tip of its tail - hence flavicauda (Fooden, 1963). But he never saw a live specimen, and his description was based on nothing more than flat, trimmed skins used as saddle covers by Peruvian muleteers near Jaen, in the Department of Cajamarca. No type specimen was preserved, and Humboldt knew so little about it that he described it as a new species of howler monkey (presently genus Alouatta) (Fooden, 1963).

For over 100 years nothing was heard of $L$. flavicauda apart from a brief mention by Poeppig (1832) of the occurrence of a 'rothe (red) choro' from Yurimaguas, in the Province of Alto Amazonas, Department of Loreto. In 1925, an animal collector named Watkins obtained two specimens from $\mathrm{La}$ Lejia (in Amazonas) for the American Museum of Natural History in New York, but these were not recognised as L. flavicauda until 1963 (Fooden, 1963). The next year Hendee, a collector for the Godman-Thomas expedition to Peru, collected three specimens at Pucatambo, at present in the Province of Rodriguez de Mendoza, Amazonas, for the British Museum in London. These three specimens were the basis of the description of L. (Oreonax) hendee $i$, a supposedly new species and subgenus of woolly monkey, by the zoologist Oldfield Thomas (1927a). In a subsequent publication the same year (1927b), Thomas raised his new subgenus to full generic status as Oreonax hendeei. Angel Cabrera (1958), the Argentinian mammalogist, believed that Thomas' hendeei was only specifically distinct from other woollies, and at the same time considered Humboldt's Simia flavicauda to be indeterminable. Finally, in 1963, the American zoologist Jack Fooden, in his revision of the woolly monkeys, pointed out that Humboldt's Simia flavicauda was in fact synonymous with Thomas' Oreonax hendeei. He also agreed with Cabrera that the animal was only distinct at a specific and not at a generic level, the correct name thus being Lagothrix flavicauda (Humboldt, 1812). From 1926, when the Hendee specimens were collected, until early 1974 - a period of nearly 50 years - nothing more was heard of this species.

\section{The 1974 Expedition}

On our 12-day expedition, April 26-May 7, in search of L. flavicauda we investigated what we believed to be the monkey's range based on Humboldt's descriptions and the 1925 and 1926 collecting localities, including forested areas in the vicinity of Chachapoyas, Mendoza and Pedro Ruiz Gallo (near a military engineering base and about two hours south of Chachapoyas by bus), all in Amazonas. From Lima we went by bus through the Peruvian coastal desert north to Chiclayo, and from there by bus and open truck on dirt roads through the mountains east to Chachapoyas and Mendoza. 


\section{HOME OF THE YELLOW-TAILED WOOLLY MONKEY}

On our second day out, we by chance met a hunter who had with him a stuffed skin and skull of an adult male $L$. flavicauda that he had shot only six days previously in montane rain forest six to seven hours by foot from Pedro Ruiz Gallo. From him we were able to get both this specimen and later three additional skins and two skulls of animals he had shot for food. (These are now deposited in the Museo de Historia Natural 'Javier Prado' of the Universidad Nacional Mayor de San Marcos in Lima, the first in any Peruvian museum.) Moreover, we went with him to the forest where he had shot the monkeys and got some idea of the habitat. By questioning people in Chachapoyas, Mendoza and Pedro Ruiz Gallo about the monkey and other animals sympatric with it, and examining the collections of several local taxidermists (a popular hobby in Peru), we were able to get a picture of the mammal and bird faunas of the area.

On our last day local children in Pedro Ruiz Gallo directed us to the home of a soldier who had a juvenile L. flavicauda, which we were able to buy. This young male is the first living representative of its species to be seen by members of the scientific community.

\section{The Habitat}

Our own observations and the reports of local people indicate that this woolly monkey occurs in montane forests at altitudes of $500-2500 \mathrm{~m}$ (Watkins's two specimens reportedly came from about $3000 \mathrm{~m}$, but we consider this somewhat high). The forests appear to be primarily Amazonian in origin, but since the area is an ecological transition zone, other non-Amazonian species occur. At least three other species of monkey, Ateles belzebuth, Cebus albifrons, Aotus trivirgatus, and possibly also Alouatta seniculus, are sympatric with L. flavicauda, and also spectacled bear Tremarctos ornatus, perhaps mountain tapir Tapirus pinchaque, and a variety of birds and other mammals (Table 1).

Until 1960 no roads went into the region. Now dirt roads have been con- 
structed, mainly by the army, and civilisation is beginning to invade. Habitat destruction on the steep mountainsides, though still minimal, is accelerating, with forests being cleared for agriculture, even on slopes so steep that cattle can barely walk on them. Monkeys, bears and other animals are hunted for food and for their skins, which are usually stuffed and sold to people in the towns. Bear skins sell for 600 soles (about US $\$ 15.00$ ) each and bear grease for 300 soles a litre. Bear meat is so valued that the hunters usually eat it themselves. Monkeys are also esteemed, as are most other medium-to-large forest mammals and birds. In one hunter's house we saw skins of a spider monkey, Ateles belzebuth, a tayra, Eira barbara, four coatis Nasua nasua, and the four L. flavicauda, the skull of a Cebus albifrons, and a bag of feathers containing the remains of about 12 cocks-of-the-rock Rupicola peruviana and a lyre-tailed nightjar Uropsalis lyra. Monkeys are sometimes hunted to obtain infants for sale as pets. The usual procedure is to shoot the mother and retrieve the infant after it has fallen to the ground, still clinging to its dead mother. Often the infant is killed as well, either by the fall or by the bullet intended for the mother. The army continues to build roads in the area and reportedly is employing professional hunters (called 'mitayeros') to shoot game to feed construction crews, a wasteful and unnecessary procedure since domestic animals are readily available.

We were able to obtain at least three new localities for L. flavicauda, but all within the bounds of the animal's previous known and very restricted range in north-eastern Cajamarca, southern Amazonas and north-western San Martin in the Andes of northern Peru. Even if it occurs further to the north and east (as appears quite possible) it still has one of the smallest geographical distributions of all New World monkeys. This fact, combined with habitat destruction and hunting pressure is sufficient reason to consider it a highly endangered species, and it is now included as a red-sheet species in the IUCN Red Data Book, on our recommendation.

\section{Recommendations}

The only species of large mammal that is endemic to Peru (although it could conceivably extend into Ecuador), this woolly monkey is an important part of Peru's faunal heritage and should be the object of special conservation measures. To publicise the animal, we held a special press conference to announce its rediscovery and the need for conservation measures on its behalf; this got coverage from the major Lima dailies, local television and several Peruvian magazines, and our live juvenile helped the cause of its species considerably by putting on several outstanding performances for the press. We have also suggested that the monkey be included in the new series of endangered species postage stamps currently being issued by the Peruvian government, along with Vicugna vicugna, Pteronura brasiliensis, Speothos venaticus, Chinchilla laniger, and Tremarctos ornatus.

Our main recommendation is that a national reserve or sanctuary be created for this rare primate to ensure its survival. This could also include populations of other interesting and endangered animals found in the region, among them the spectacled bear, mountain tapir, cock-of-the-rock, and the rare and beautiful hummingbird, Loddigesia mirabilis, also endemic to the area and even more restricted in range than the monkey.

To determine the most suitable locality for a reserve or sanctuary, we are 
Table 1 Some birds and mammals recorded from the range of $L$. flavicauda in the Peruvian department of Amazonas*

Birds

Turkey vulture

Black-and-chestnut-eagle

American kestrel

Andean guan

Sunbittern

Scarlet-fronted parakeet

Squirrel cuckoo

Lyre-tailed nightjar

Sparkling violetear

Marvellous spatuletail

Cock-of-the-rock

Tropical kingbird

Green jay

Violaceous jay

Scarlet-rumped cacique

Carbonated flower-piercer

Blue-necked tanager

Silver-beaked tanager

Hepatic tanager

Black-beaked grosbeak

\section{Mammals}

Opossum

Night monkey

White-fronted capuchin monkey

Spider monkey

Spectacled bear

Coati

Long-tailed weasel

Tayra

Jaguarundi

White-lipped peccary

White-tailed deer

Paca

Prehensile-tailed porcupine
Cathartes aura

Oreoaetus isidori

Falco sparverius

Penelope montagnii

Eurypyga helias

Aratinga wagleri

Piaya cayana

Uropsalis lyra

Colibri coruscans

Loddigesia mirabilis

Rupicola peruviana

Tyrannus melancholicus

Cyanocorax yncas

Cyanocorax violaceus

Cacicus uropygialis

Diglossa carbonaria

Tangara cyanicollis

Ramphocelus carbo

Piranga flava

Pheucticus aureoventris

Didelphis marsupialis

Aotus trivirgatus

Cebus albifrons

Ateles belzebuth

Tremarctos ornatus

Nasua nasua

Mustela frenata

Eira barbara

Felis yagouaroundi

Tayassu pecari

Odocoileus virginianus

Cuniculus paca

Coendou bicolor

* Based on the author's field observations, specimens in local taxidermy collections and information from local inhabitants.

currently planning several longer and more detailed surveys to be conducted under the auspices of the Museo de Historia Natural of the Universidad Nacional Mayor de San Marcos and the Servicio Forestal y Caza (Wildlife Service) of the Peruvian Ministry of Agriculture.

Thanks to the efforts of Peruvian and foreign conservationists and scientists, especially a number of very active people in the Ministry of Agriculture and the universities of Peru, and the success of the national and international campaigns to save the vicuña, the Peruvian government and public are becoming more and more receptive to wildlife conservation measures. We have every hope that rapid action will be taken on behalf of this attractive rare monkey, and that it will eventually become, like the vicuña, a symbol of the dynamic and successful Peruvian conservation movement. 


\section{Acknowledgments}

We would like to thank Dr Marc Dourojeanni Ricordi, Director General de Forestal y Caza, Ing. Carlos Ponce del Prado, Director de Fauna Silvestre, and Dr Antonio Brack Egg, Sub-Director de Conservación de la Fauna Silvestre of the Ministerio de Agricultura del Peru for their co-operation in all phases of this project.

\section{References}

CABRERA, A. 1958. Catalogo de los mamiferos de America del Sur, I. Cienc. Zool. 4 (1). Mus. Arg. Cienc, Nat. 'Bernardino Rivadavia', Buenos Aires, pp. iv +308.

FOODEN, J. 1963. A revision of the woolly monkeys (genus Lagothrix). J. Mammal. 44 (2): 213-247.

HUMBOLDT, A. von and BONPLAND, A. 1812. Recueil d'observations de zoologie et d'anatomie comparée. Vol. 1. F. Schoell and G. Dufour and Co., Paris, pp. viii +368.

POEPPIG, E. 1832. Doctor Poepig's naturhistorische Reiseberichte. Notizen aus dem Gebiete der Natur- und Heilkunde 33 (7): cols. 97-106.

THOMAS, O. 1927a. A remarkable new monkey from Peru. Ann. Mag. Nat. Hist. (9) 19: 156-157.

THOMAS, O. 1927b. The Godman-Thomas Expedition to Peru. VI. On mammals from the Upper Huallaga and neighbouring highlands. Ann. Mag. Nat. Hist. (9) 20: 594-608.

Authors' addresses:

Russell A. Mittermeier, Museum of Comparative Zoology and Dept. of Anthropology, Harvard University, Cambridge, Mass. 02138, USA.

Hernando de Macedo-Ruiz, Head of the Dept. of Ornithology and Mammalogy, Museo de Historia Natural, Universidad Nacional Mayor de San Marcos, Apartado 1109, Lima, Peru, to whom requests for reprints should be sent.

B. Anthony Luscombe, Atahualpa 335, Miraflores, Lima, Peru.

\section{Llamas in Ecuador}

Dr Armando Cardozo a member of FPS, writes:

Last year Ecuador took the first steps towards creating the Cotopaxi National Park on the slopes of the magnificent mountain of that name. It is hoped that vicuñas will be reintroduced in this park - they have long been extinct in Ecuador - and meanwhile the Forestry Service has brought in 23 llamas and hopes to increase the number.

Of the four camelids in South America today, all of which originated in the High Andes, only the vicuña and the guanaco are found wild; the llama and the alpaca are known only as domestic animals. Both were domesticated before the Spaniards arrived and possibly as far back as $4000 \mathrm{BC}$. There are many llamas in other South American countries - Bolivia 1,800,000, Peru 954,000, Argentina 75,000 and Chile 64,000 , but in Ecuador the numbers are slowly decreasing and probably only total about 2000 .

\section{Priorities in Southern Africa}

A list of nature conservation priorities for southern Africa has been compiled by the South Africa Nature Foundation which is affiliated to WWF. The countries covered include Angola, Botswana, Lesotho, Malawi, Mozambique, Rhodesia, South Africa, South West Africa, Swaziland, and adjacent islands and oceans. The categories listed cover the whole conservation spectrum under three special headings: wild species, special landscapes and communities; man and environment interactions; education and information. A series of tables show the status of the larger mammals in all eight countries, and a report by Dr Hey, Director of the Cape Nature Conservation Department, assesses the rare and endangered birds, reptiles and amphibia. 